\title{
SUBSTRATES AND LIGHT CONDITIONS IN THE GROWTH OF SEEDLINGS OF Parkia multijuga BENTH.
}

\author{
Luiz Maekawa ${ }^{1}$, Maria de Fatima Barbosa Coelho ${ }^{2 *}$ \\ ${ }^{1}$ Instituto Federal de Educação, Ciência e Tecnologia de Mato Grosso, Campus Juína, Juína. MT, Brasil - maekawaluizjr@ hotmail.com \\ ${ }^{2 *}$ Programa de Pós-Graduação em Agricultura Tropical da Universidade Federal de Mato Grosso. Cuiabá, MT, Brasil - e-mail: \\ coelhomfstrela@gmail.com \\ Received for publication: 07/02/2020 - Accepted for publication: 05/06/2020
}

\begin{abstract}
Resumo
Substratos e condições de luz no crescimento de mudas de Parkia multijuga Benth. A espécie florestal Parkia multijuca Benth. ocorre no noroeste do estado de Mato Grosso, região amazônica brasileira, importante para a recuperação de áreas degradas, principalmente por seu rápido crescimento. O objetivo deste estudo foi identificar as melhores combinações de substratos e condições de luz para o desenvolvimento de mudas de Parkia multijuga em viveiro. O delineamento experimental utilizado foi blocos casualizados em esquema de parcela subdividida 4 x 11 com 4 repetições. As condições de luz foram sol pleno, 30\%, 50\% e 70\% de sombreamento. Os substratos foram $1-$ Solo, 2 - Solo + calcário, 3 - Solo + calcário + esterco bovino, 4 - Solo + calcário + superfosfato simples, 5 - Solo + calcário + superfosfato simples + esterco de bovino, 6 - Solo + termofosfato e 7 - Solo + termofosfato + bokashi. Os parâmetros morfológicos utilizados foram altura da muda, diâmetro, número de folhas, massa seca total, massa de parte aérea, massa seca de raízes, relação entre altura e diâmetro, altura e massa seca da parte aérea, entre massa seca da parte aérea e massa seca da raiz e o índice de qualidade de Dickson (IQD). Mudas de Parkia multijuga de maior qualidade podem ser produzidas em viveiro em pleno sol e em substrato com $25 \%$ de esterco bovino. O sombreamento não deve ser utilizado na produção de mudas de Parkia multijuga.

Palavras-chave: Sombreamento, Índice de qualidade de Dickson, adubação orgânica, parâmetros morfológicos
\end{abstract}

\section{Abstract}

The forest species Parkia multijuca Benth. is found in northwestern Mato Grosso State, Brazilian Amazon region, being important for the recovery of degraded areas of permanent preservation mainly for its rapid growth. The aim of this study was to identify the best combinations of substrates and light conditions for the seedling development of Parkia multijuga in a nursery. The experiment was conducted in a randomized block design, arranged in a $4 \mathrm{x} 11$ plot scheme with four replicates. The light conditions evaluated were full sun and $30 \%, 50 \%$, and $70 \%$ shading. The following substrates were evaluated: 1 - Soil; 2 - Soil + limestone "filler"; 3 - Soil + limestone + cattle manure; 4 Soil + limestone + simple superphosphate; 5 - Soil + limestone + simple superphosphate + cattle manure; 6 - Soil + thermophosphate; and 7 - Soil + thermophosphate + bokashi. The morphological parameters used were shoot height, shoot diameter, number of leaves, total dry mass, shoot mass, root dry mass; the ratios between height and diameter, shoot height and shoot dry mass, and shoot dry mass and root dry mass; and the Dickson Quality Index (DQI). The seedlings of Parkia multijuga can be produced in a nursery with higher quality in full sun and in substrate with $25 \%$ cattle manure. Shading should not be used in the seedling production of Parkia multijuga.

Keywords: Shading, Dickson quality index, organic fertilization, morphological parameters

\section{INTRODUCTION}

Parkia multijuca Benth. is one of the forest species that occurs in northwestern Mato Grosso State, Brazilian Amazon region. Popularly known in Amazonas State as faveira, faveira-benguê, and paricá-de-terrafirme, in Mato Grosso State as bajão, in Pará State as faveira-arara-tucupi, and in Rondônia State as pinhocuiabano, it is distributed in the Amazonas, Pará, Maranhão, Acre, Rondônia, and Mato Grosso (OLIVEIRA; HOPKINS, 2018).

Parkia multijuga can be used in landscaping, especially in urban arborization and public squares, besides being important for the recovery of degraded areas of permanent preservation, mainly for its rapid growth (LORENZI, 2008).

Advances in research on forest species have been significant in recent years, but the information available on native forest species is still scarce. In the process of seedling production in nurseries, the substrate available for the roots is fundamental, since it is the environment where planting and the subsequent support to the plants occur through the supply of water, nutrients, and oxygen to the root system.

In Brazil, cattle manure has been used in various compositions and proportions in substrates for seedling production. Vieira et al. (2014) pointed out that the seedling diameter of Calophyllum brasiliense was influenced by the addition of organic sources in the substrate formulation, adding that this occurs as the organic sources increase substrate fertility. Padilha et al. (2018) verified that the use of organic substrate from composting improved the seedling quality of Peltophorum dubium in relation to the commercial substrate, being a viable option for seedling production of forest species.

The effect of shading on seedlings at nursery stage also interferes with plant development, and the development under controlled conditions with the use of artificial shading by using a screen allows verifying the

FLORESTA, Curitiba, PR, v. 51, n. 3, p. 623-629, jul/set 2021. 
tolerance of the species to the amount of light received (BORGES et al., 2014). Pinto et al. (2016) observed in Tabebuia aurea that seedling growth was not influenced by the luminosity to which they were submitted. Lenhard et al. (2013) observed in Caesalpinia ferrea that the species presented better growth rates when maintained under 50\% shading, and Santos et al. (2013) observed that the highest growth of Erythrina velutina occurred in full sun.

Farmers in northwestern Mato Grosso State have shown interest in the planting of Parkia multijuga, although there are no seedlings available and no technology for their production. It is expected that seedlings may develop differently when subjected to restrictions in the amount of light received and different substrate compositions. Thus, the present study aims to identify the best combinations of substrates and light conditions for the development of seedlings of Parkia multijuga in a nursery.

\section{MATERIAL AND METHODS}

The study was conducted at the Federal Institute of Education, Science and Technology of Mato Grosso (IFMT), located in the municipality of Juína, Mato Grosso State (11'26'48.9" S and 58 43'22.0" W, altitude of $311 \mathrm{~m})$. According to Köppen - Geiger classification, the climate of Juína is Aw, tropical with dry season in winter. The highest monthly precipitation occurs in January with $335.12 \mathrm{~mm}$ and the lowest in July with 1.88 $\mathrm{mm}$, defining the region with two seasons, a dry season from May to September and a rainy season from October to April. The months of December, January, February and March present $90 \%$ probability of occurrence of rainfall over $160 \mathrm{~mm}$.

Parkia multijuga pods were collected in February 2016 in the municipality of Juína at coordinates $11^{\circ} 22^{\prime} 09.5$ "S and $58^{\circ} 45^{\prime} 27.6^{\prime \prime} \mathrm{W}$, with the seeds being packed in plastic bags in the IFMT room under ambient conditions. In October 2016, the seeds were mechanically scarified on the opposite side of the radicle to overcome dormancy and immersed in a bucket with water for three six-hour periods with 30 minute intervals for oxygenation. These water soaked seeds were transported to suspended germinators filled with sawdust powder substrate and covered with $1 \mathrm{~cm}$ of sawdust, where the seeds remained for 7-8 days. After this period, the integuments surrounding the seeds were manually removed and placed in different containers with the commercial substrate Plantmax Florestal ${ }^{\circledR}$. The complete emergence of all seedlings occurred in November 10 , 2016.

The experiment was conducted in a randomized block design arranged in 4 x 11 plot scheme, with four replicates with 20 plants. The light conditions evaluated were full sun and $30 \%$, 50\%, and $70 \%$ shading, constituting the plots. The subplots were the following substrates: 1 - Topsoil (control); 2 - Topsoil + limestone "filler" - PRNT 99.15 - 1g/liter of soil; 3 - Topsoil (75\% v) + limestone (1g/liter) + cattle manure (25\% v); 4 Topsoil + limestone + simple superphosphate $(1 \mathrm{~g} /$ liter $) ; 5$ - Topsoil + limestone + simple superphosphate $(1 \mathrm{~g} /$ liter $)+$ cattle manure $(25 \% \mathrm{v}) ; 6$ - Topsoil + thermophosphate - 1g/liter; 7 - Topsoil + thermophosphate + bokashi. Topsoil was removed at a depth of $20 \mathrm{~cm}$. The analysis is shown in S1 (Table 1).

Table 1. Chemical and physical analyzes of the substrates used to produce seedlings of Parkia multijuga Benth. in Juína Campus, IFMT. Laboratory of EMPAER-MT, 2018.

Tabela 1. Análises químicas e físicas dos substratos utilizados para produzir mudas de Parkia multijuga Benth. no campus de Juína, IFMT. Laboratório da EMPAER-MT. 2018.

\begin{tabular}{|c|c|c|c|c|c|c|c|}
\hline Chemical analysis & S1 & S2 & S3 & S4 & S5 & S6 & S7 \\
\hline $\mathrm{pH}\left(\mathrm{H}_{2} \mathrm{O}\right)$ & 5.2 & 6.5 & 6.4 & 6.5 & 6.5 & 6.4 & 6.4 \\
\hline $\mathrm{pH}\left(\mathrm{CaCl}_{2}\right)$ & 4.3 & 5.7 & 5.7 & 5.8 & 5.8 & 5.6 & 5.6 \\
\hline $\mathrm{P}\left(\mathrm{mg} / \mathrm{dm}^{3}\right)$ & 0.75 & 0.65 & 65.0 & 33.3 & 93.9 & 17.3 & 18.9 \\
\hline $\mathrm{K}\left(\mathrm{cmolc} / \mathrm{dm}^{3}\right)$ & 0.06 & 0.07 & 0.13 & 0.09 & 0.13 & 0.09 & 0.1 \\
\hline $\mathrm{Ca}+\mathrm{Mg}\left(\mathrm{cmolc} / \mathrm{dm}^{3}\right)$ & 0.7 & 1 & 1.4 & 0.9 & 1.6 & 0.9 & 1 \\
\hline $\mathrm{Ca}\left(\mathrm{cmolc} / \mathrm{dm}^{3}\right)$ & 0.6 & 0.8 & 1.2 & 0.7 & 1.3 & 0.7 & 0.8 \\
\hline $\mathrm{Mg}\left(\mathrm{cmolc} / \mathrm{dm}^{3}\right)$ & 0.2 & 0.2 & 0.3 & 0.2 & 0.3 & 0.2 & 0.3 \\
\hline $\mathrm{Al}\left(\mathrm{cmolc} / \mathrm{dm}^{3}\right)$ & 0.1 & 0 & 0 & 0 & 0 & 0 & 0 \\
\hline $\mathrm{H}+\mathrm{Al}$ molc $\left./ \mathrm{dm}^{3}\right)$ & 1.6 & 0.9 & 1 & 1 & 1.1 & 0.9 & 0.9 \\
\hline M. O. $\left(\mathrm{g} / \mathrm{dm}^{3}\right)$ & 6.8 & 6 & 17.3 & 8 & 18.8 & 8.3 & 6.3 \\
\hline $\mathrm{S}\left(\mathrm{cmolc} / \mathrm{dm}^{3}\right)$ & 0.78 & 1.02 & 1.55 & 0.99 & 1.7 & 1.02 & 1.13 \\
\hline CTC $\left(\mathrm{cmolc} / \mathrm{dm}^{3}\right)$ & 2.38 & 1.9 & 2.5 & 1.99 & 2.83 & 1.94 & 1.98 \\
\hline $\mathrm{V}(\%)$ & 33.3 & 54.8 & 61.3 & 49.8 & 60.3 & 53.8 & 57.3 \\
\hline Al Sat (\%) & 11.3 & 0 & 0 & 0 & 0 & 0 & 0 \\
\hline Sand $(\mathrm{g} / \mathrm{kg})$ & 740 & 750 & 740 & 740 & 745 & 740 & 745 \\
\hline Silt $(\mathrm{g} / \mathrm{kg})$ & 60,0 & 55 & 70 & 60 & 70 & 65 & 60 \\
\hline Clay $(\mathrm{g} / \mathrm{kg})$ & 200 & 195 & 190 & 200 & 185 & 195 & 195 \\
\hline
\end{tabular}

Legend: S1 - Topsoil (control); S2 - Topsoil + limestone "filler" - PRNT 99.15 - 1g/liter of soil; S3 - Topsoil (75\% v) + limestone (1g/liter) + cattle manure $(25 \% \mathrm{v})$; S4 - Topsoil + limestone + simple superphosphate (1g/liter); S5 - Topsoil + limestone + simple superphosphate $(1 \mathrm{~g} / \mathrm{liter})+$ cattle manure $(25 \% \mathrm{v}) ; \mathrm{S} 6$ - Topsoil + thermophosphate - 1g/liter; S7 - Topsoil + thermophosphate + bokashi. 
Irrigation was performed with a Micro sprinkler system in two shifts of 20 minutes (at 9:00h and 16:00h), being equivalent to an average of $5 \mathrm{~mm}$ per day.

At 180 days, seedlings were evaluated by measuring the neck diameter and height, counting the number of leaves, and determining biomass. The plants were washed and dried for 48 hours at a temperature of $65^{\circ} \mathrm{C}$ in a drying oven with forced air circulation (Solab, model SL-102) at the IFMT. Shoot and root dry mass were obtained using an electronic scale (Edutec, model EJ-320 A) with 0.01g precision.

The data obtained were used to calculate the following allometric ratios: the ratio between shoot height and shoot diameter (H/D), the ratio between shoot height and shoot dry mass (H/SDM), the ratio between root dry mass and shoot dry mass (SDM/RDM), the ratio between root and shoot dry mass (RDM/SDM), and the Dickson quality index (DQI) (Dickson et al., 1960).

The data were submitted to analysis of variance and F test and the means were compared by the Tukey test at $5 \%$ probability level using the software SISVAR.

\section{RESULTS}

The analysis of variance of the characteristics studied in Parkia multijuga did not indicate significant interaction between substrate composition and light condition. However, isolated effect of substrate composition and light condition was observed (Table 2 and 3 ).

Table 2. Diameter (D), plant height (H), number of leaves (LF), root dry mass (RDM), shoot dry mass (SDM), total dry mass (TDM), ratios between height and diameter (H/D), shoot height and shoot dry mass (H/SDM), shoot dry mass and root dry mass (SDM/RDM), root dry mass and shoot dry mass (RDM/SDM), and Dickson Quality Index (DQI) of seedlings of Parkia multijuga Benth. under different light conditions. Juína-MT, 2018.

Tabela 2. Diâmetro (D), altura da planta (H), número de folhas (NF), massa seca das raízes (MSRA), massa seca da parte aérea (MSPA), massa seca total (MST), relação entre altura e diâmetro (H/D), altura e massa de parte aérea (H/MSPA), massa seca de parte aérea e massa seca de raiz (MSPA/MSRA), massa seca de raiz e massa seca de parte aérea (MSRA/MSPA) e índice de qualidade de Dickson (IQD) de mudas de Parkia multijuga Benth. sob diferentes condições de luz. Juína-MT, 2018.

\begin{tabular}{|c|c|c|c|c|c|c|c|c|c|c|c|}
\hline $\begin{array}{l}\text { Shading } \\
(\%)\end{array}$ & $\begin{array}{c}\mathbf{D} \\
(\mathbf{m m})\end{array}$ & $\begin{array}{c}\mathbf{H} \\
(\mathbf{c m})\end{array}$ & $\mathbf{L F}$ & $\begin{array}{c}\text { RDM } \\
\text { (g) }\end{array}$ & $\begin{array}{c}\text { SDM } \\
\text { (g) }\end{array}$ & $\begin{array}{c}\text { TDM } \\
\text { (g) }\end{array}$ & H/D & $\begin{array}{c}\text { H/ } \\
\text { SDM }\end{array}$ & $\begin{array}{l}\text { SDM/ } \\
\text { RDM }\end{array}$ & $\begin{array}{l}\text { RDM/ } \\
\text { SDM }\end{array}$ & IQD \\
\hline 0 & $10.61 \mathrm{a}$ & $46.00 \mathrm{~b}$ & $6.17 a$ & $45.16 \mathrm{a}$ & $117.80 \mathrm{a}$ & $162.96 \mathrm{a}$ & $4.37 \mathrm{c}$ & $0.40 \mathrm{c}$ & $2.58 \mathrm{~b}$ & $0.39 \mathrm{a}$ & $40.19 a$ \\
\hline 30 & $9.73 b$ & $53.60 \mathrm{a}$ & $5.46 \mathrm{~b}$ & $37.29 \mathrm{~b}$ & $107.99 a$ & $145.28 \mathrm{ab}$ & $5.58 b$ & $0.54 \mathrm{~b}$ & $2.83 \mathrm{~b}$ & $0.35 b$ & $29.67 b$ \\
\hline 50 & $9.71 b$ & $56.85 \mathrm{a}$ & $5.33 b$ & $30.80 \mathrm{~b}$ & $102.05 \mathrm{ab}$ & $132.84 b c$ & $5.58 b$ & $0.59 \mathrm{ab}$ & $3.28 \mathrm{a}$ & $0.30 \mathrm{c}$ & $26.14 b$ \\
\hline 70 & $8.77 \mathrm{c}$ & $54.65 \mathrm{a}$ & $5.66 \mathrm{~b}$ & $26.77 \mathrm{c}$ & $87.38 b$ & $114.15 \mathrm{c}$ & $6.26 \mathrm{a}$ & $0.64 \mathrm{a}$ & $3.27 \mathrm{a}$ & $0.31 \mathrm{c}$ & $21.76 \mathrm{c}$ \\
\hline
\end{tabular}

* Equal lowercase letters in the column indicate no significant difference between the light conditions according to Tukey test at $5 \%$ probability.

Table 3. Diameter (D), plant height (H), number of leaves (LN), root dry mass (RDM), shoot dry mass (SDM), total dry mass (TDM), ratios between height and diameter (H/D), shoot height and shoot dry mass (H/SDM), shoot dry mass and root dry mass (SDM/RDM), root dry mass and shoot dry mass (RDM/SDM), and Dickson Quality Index (DQI) of seedlings of Parkia multijuga Benth. under different substrate compositions. Juína-MT, 2018.

Tabela 3. Diâmetro, altura da planta, número de folhas, massa seca da raiz, massa seca da parte aérea, massa seca total, relação entre altura e diâmetro (H/D), altura e massa da parte aérea (H/MSPA), massa seca da parte aérea e raiz seca massa (MSPA/MSRA), massa seca da raiz e massa seca da parte aérea (MSRA/MSPA) e Índice de Qualidade de Dickson (IQD) de mudas de Parkia multijuga Benth. sob diferentes composições de substrato. Juína-MT, 2018.

\begin{tabular}{|c|c|c|c|c|c|c|c|c|c|c|c|}
\hline Substrate & $\begin{array}{c}\text { D } \\
(\mathrm{mm})\end{array}$ & $\begin{array}{c}\mathbf{H} \\
(\mathbf{c m})\end{array}$ & $\mathbf{L N}$ & $\begin{array}{c}\text { RDM } \\
(\mathrm{g})\end{array}$ & $\begin{array}{c}\text { SDM } \\
(\mathrm{g})\end{array}$ & $\begin{array}{c}\text { TDM } \\
\text { (g) }\end{array}$ & H/D & $\begin{array}{c}\text { H/ } \\
\text { SDM }\end{array}$ & $\begin{array}{l}\text { SDM/ } \\
\text { RDM }\end{array}$ & $\begin{array}{l}\text { RDM/ } \\
\text { SDM }\end{array}$ & IQD \\
\hline 1 & $9.37 b$ & $48.96 \mathrm{~b}$ & $5.57 \mathrm{bc}$ & $32.24 b$ & $91.76 b$ & $123.99 \mathrm{~b}$ & $5.31 \mathrm{a}$ & $0.56 \mathrm{a}$ & $2.89 \mathrm{~b}$ & $0.35 \mathrm{a}$ & $27.88 b$ \\
\hline 2 & $8.83 b$ & $48.44 b$ & $5.43 \mathrm{c}$ & $28.74 b$ & $78.11 \mathrm{~b}$ & $106.85 b$ & $5.65 \mathrm{a}$ & $0.64 a$ & $2.79 \mathrm{~b}$ & $0.36 \mathrm{a}$ & $23.31 b$ \\
\hline 3 & $11.40 \mathrm{a}$ & $62.98 \mathrm{a}$ & $6.23 \mathrm{ab}$ & $48.89 \mathrm{a}$ & $157.38 \mathrm{a}$ & $206.27 \mathrm{a}$ & $5.56 \mathrm{a}$ & $0.42 b$ & $3.27 \mathrm{a}$ & $0.31 b$ & $41.44 \mathrm{a}$ \\
\hline 4 & $8.88 \mathrm{~b}$ & $48.52 b$ & $5.26 \mathrm{c}$ & $28.59 b$ & $80.67 \mathrm{~b}$ & $109.25 b$ & $5.35 \mathrm{a}$ & $0.61 \mathrm{a}$ & $2.90 \mathrm{~b}$ & $0.35 \mathrm{a}$ & $23.48 b$ \\
\hline 5 & $11.33 \mathrm{a}$ & $62.87 \mathrm{a}$ & $6.45 a$ & $46.77 \mathrm{a}$ & $148.05 \mathrm{a}$ & $194.82 \mathrm{a}$ & $5.58 \mathrm{a}$ & $0.44 b$ & $3.25 \mathrm{a}$ & $0.32 b$ & $38.98 \mathrm{a}$ \\
\hline 6 & $9.11 \mathrm{~b}$ & $47.94 b$ & $5.45 \mathrm{c}$ & $30.44 b$ & $86.27 \mathrm{~b}$ & $116.71 \mathrm{~b}$ & $5.35 \mathrm{a}$ & $0.58 \mathrm{a}$ & $2.92 \mathrm{~b}$ & $0.36 \mathrm{a}$ & $26.70 b$ \\
\hline 7 & $9.05 \mathrm{~b}$ & $49.76 b$ & $5.21 \mathrm{c}$ & $29.36 \mathrm{~b}$ & $84.43 b$ & $113.78 \mathrm{~b}$ & $5.55 \mathrm{a}$ & $0.60 \mathrm{a}$ & $2.92 \mathrm{~b}$ & $0.36 \mathrm{a}$ & $24.33 b$ \\
\hline
\end{tabular}

* Equal lowercase letters in the column indicate no significant difference between the light conditions according to Tukey test at 5\%
probability.

** Legend: 1 - S1 - Surface soil (control); S2 - Soil + limestone "filler" - PRNT 99.15 - 1g/liter of soil; S3 - Soil (75\% v) + limestone $(1 \mathrm{~g} /$ liter $)+$ cattle manure $(25 \% \mathrm{v}) ; \mathrm{S} 4$ - Soil + limestone + simple superphosphate $(1 \mathrm{~g} / \mathrm{liter}) ; \mathrm{S} 5$ - Soil + limestone + simple superphosphate $(1 \mathrm{~g} / \mathrm{liter})+$ cattle manure $(25 \% \mathrm{v})$; S6 - Soil + thermophosphate - 1g/liter; S7 - Soil + thermophosphate + bokashi. 
The seedlings of Parkia multijuga presented the largest diameter in full sun condition, while the smallest were observed with $70 \%$ of shading (Table 2).

The greatest plant height of Parkia multijuga was observed for seedlings produced under light restriction and the smallest for seedlings under full sun (Table 2). The number of leaves presented the same behavior as the diameter, with a higher number in the full sun condition. Dry mass values (TDM, RDM, and SDM), RDM/SDM, and IQD were higher at full sun, while the H/D, H/SDM, and SDM/RDM ratios were higher at shading (Table 2).

Regarding substrate, those with the addition of cattle manure + limestone (S3) or cattle manure + limestone + chemical fertilizer (S5) showed higher values in relation to the other treatments (Table 3 ).

\section{DISCUSSION}

It was noted that as the light restriction increased, plant diameter decreased (Table 2). The increase in diameter of seedlings with greater light availability occurs, according to Taiz et al. (2017), since the increase of shading decreases photosynthesis, consequently decreasing the amount of photoassimilates and growth regulators, causing the reduction in diameter. However, it is necessary to consider the successional group to which the species belongs. Parkia multijuga belongs to the group of pioneers, therefore being a species that is not tolerant to shading.

In studies with arboreal species indicated for reforestation under clearing conditions and with intermediate shading, increased growth in diameter has been verified at $50 \%$ shade in a nursery, as observed by Valadão et al. (2014) in Physocalymma scaberrimum Pohl and by Lenhard et al. (2013) at Caesalpinia ferrea Mart. ex. Tul. var. leiostachya Benth.

Regarding the increase in height with greater shading, similar results were found by Rosa et al. (2009) in studies with Schizolobium amazonicum Huber ex Ducke. On the other hand, Conceição and Dias-Filho (2013), who studied seedlings of Sclerolobium paniculatum Vogel, verified that those cultivated under 50 and $75 \%$ of shading grew more in height than seedlings grown under $25 \%$ shading.

Frigotto et al. (2015), who studied the seedling growth of Schizolobium amazonicum in different environments in the nursery, found that shading changes of $75 \%$ in a greenhouse provided greater mean height and diameter at 280 days, concluding that shading has a positive effect on plants.

According to Gomes and Paiva (2012), diameter and height are fundamental for evaluating the potential of survival and growth in the post-planting of seedlings of forest species. Within the same species, plants with larger diameter present greater survival, since they have the capacity to form and grow new roots.

The number of leaves differed from other authors, such as Nery et al. (2018), who observed a larger number of leaves under conditions of $30 \%$ and $50 \%$ shading for Calophyllum brasiliense Cambess. According to Albuquerque, Evangelista and Albuquerque Neto (2015), differences in the number of leaves of Bertholletia excelsa Blonp. under full sun, 25, 50, and 75\% shading were not observed. Reis et al. (2015) observed that seedlings of Dilodendron bipinnatum Radkl. presented a larger number of leaves in treatments under full sun and with $50 \%$ shading.

The reduction of RDM accumulation may be related to a decrease in the downward flow of assimilates of photosynthetic organs as the light restriction increased, since light is one of the determinants for this directional transport (RESENDE et al., 2011). According to Taiz et al. (2017), plants under light restriction tend to direct their metabolism to the synthesis of nonstructural carbohydrates aiming at greater survival capacity, reducing root dry mass accumulation. SDM was less affected by shading, since seedlings only presented biomass reduction under $70 \%$ shading (Table 2 ).

H/D and H/SDM ratios increased proportionally with shading (Table 2). Cruz et al. (2011) found that 120-day seedlings of Peltophorum dubium presented a H/D ratio between 2.89 and 4.61, close to that found in the present study. According to results obtained by Souza et al. (2017), seedlings with higher H/D ratios showed a better balance in their development, being more robust. When the H/D ratio is very high, the seedlings should remain longer in the nursery to reduce the imbalance between these variables and ensure a greater success of the transplant in the field (PADILHA et al., 2018).

Lower H/D ratios provide greater seedling robustness and better planting adaptation. Thus, the seedlings developed under full sun in the present study are better. Increased exposure to photosynthetic radiation increases the assimilate partition into the root system by decreasing the ratio values.

Regarding the H/SDM ratio, according to the literature, the lower the ratio, the higher the quality of the seedlings produced (CRUZ et al., 2011). According to Gomes and Paiva (2012), the H/SDM ratio demonstrates that the lower the value, the greater the chance of survival of seedlings in the field, being an indication of how much plants are lignified. 
DQI values were very high when compared with the minimum required of 0.20 (GOMES; PAIVA, 2012). Thus, the seedlings under all light conditions in this study were adequate, since they presented values above 0.20 .

The favorable effect of the presence of cattle manure for all characteristics evaluated can be due to the greater nutrient intake and the better conditions of aeration and water storage available for plant roots (Table 1). Cattle manure may have functioned as a reservoir of nutrients and moisture, besides ensuring good soil aeration, providing micronutrients and increasing the nutrient availability for plants, favoring seedling growth (Table 3).

Thus, both root dry mass (RDM), shoot dry mass (SDM), and total dry mass (TDM) were approximately twofold higher compared to the other substrates, with the highest values observed in substrates S3 and S5.

The shoot and root dry mass (SDM/RDM) ratio was higher in substrates S3 and S5, while the reverse ratio $(\mathrm{RDM} / \mathrm{SDM})$ was lower in these conditions. The SDM/RDM ratio ranged from two to three in different treatments, according to the literature. Gomes and Paiva (2011) cited that two is the best ratio between shoot and root dry mass. Table 3 shows that the seedlings produced in substrates S3 and S5 showed higher DQI, 41.44 and 38.98, respectively.

In the study by Trazzi et al. (2012), it was found that animal manures in the proportions of 15, 25 or $35 \%$ provided improvement in the chemical and physical attributes of the substrates used in forest seedlings. Regarding chemical attributes, there was an increase in the total available contents and in the cation exchange capacity, base sum, and base saturation as the proportion of manure in the substrates increased.

Zanatta et al. (2016), who studied different substrate combinations in the seedling production of Tabebuia impetiginosa, reported greater plant height with the addition of organic compounds. However, different substrate compositions may lead to different growth responses. Lisboa et al. (2018) verified that the use of cattle manure in the proportion of $21 \%$ to $28 \%$ improved the chemical characteristics of the substrates, contributing to both the growth increase and the quality of seedlings of Handroanthus heptaphyllus. Gonçalves et al. (2014) recommended adding bovine manure at the rate of at least $20 \%$ of the substrate volume in the substrate composition for the seedling production of Ateleia glazioviana. In the present study, $25 \%$ of bovine manure in the substrate composition proved to be the best.

\section{CONCLUSIONS}

- Seedlings of Parkia multijuga can be produced in a nursery with higher quality under full sun and in substrate with $25 \%$ cattle manure.

- $\quad$ Shading should not be used in the seedling production of Parkia multijuga.

\section{REFERENCES}

ALBUQUERQUE, T.C.S.; EVANGELISTA, T.C.; ALBUQUERQUE NETO, A.A.R. Níveis de sombreamento no crescimento de mudas de castanheira do Brasil. Revista Agro@mbiente, Boa Vista, v. 9, n .4, p.440-445, 2015. Avaialable: < http://dx.doi.org/10.18227/1982-8470ragro.v9i4.3025 > Acessed in: 12 dez. 2019.

BORGES, V.P.; COSTA, M.A.P.C.; RIBAS, R.F. Emergência e crescimento inicial de Tabebuia heptaphylla (Vell.) Toledo em ambientes contrastantes de luz. Revista Árvore, Viçosa, v. 38, n. 3, p.523-531, 2014. Avaialable: < http://dx.doi.org/10.1590/S0100-67622014000300015 > Acessed in: 10 dez. 2019.

CONCEIÇÃO, A.C.; DIAS-FILHO, M.B. Níveis de sombreamento para produção de mudas de taxi-branco (Sclerolobium paniculatum Vogel). Revista do Instituto Florestal, São Paulo, v. 25, n. 2, p.151-161, 2013. Avaialable: $\quad<$ https://ainfo.cnptia.embrapa.br/digital/bitstream/item/102964/1/RIF25-2-151-161.pdf > Acessed in: 20 nov. 2019.

CRUZ C.A.F. et al. Macronutrientes na produção de mudas de canafístula em argissolo vermelho amarelo da região da Zona da Mata, MG. Ciência Florestal, Santa Maria, v. 21, n. 3, p.445-457, 2011a. Avaialable: < https://periodicos.ufsm.br/cienciaflorestal/article/view/3802/2212 > Acessed in: 20 out. 2019.

CRUZ, C.A.F. et al. Efeito de macronutrientes sobre o crescimento e qualidade de mudas de canafístula cultivadas em Latossolo Vermelho-Amarelo distrófico. Revista Árvore, Viçosa, v. 35, n. 5, p.983-999, 2011 b. Avaialable: < http://dx.doi.org/10.1590/S0100-67622011000600004 > Acessed in: 10 set. 2019.

DICKSON, A.; LEAF, A.L.; HOSNER, J.F. Quality appraisal of white spruce and white pine seedling stock in nurseries. Forest Chronicles, Toronto, v. 36, n. 1, p.10-13, 1960. Avaialable: < https://pubs.cififc.org/doi/pdf/10.5558/tfc36010-1> Acessed in: 10 ago. 2019. 
FRIGOTTO, T. et al. Desenvolvimento de mudas de Schizolobium amazonicum Huber ex Ducke em diferentes ambientes em viveiro. Ecologia e Nutrição Florestal, Santa Maria, v. 3, n. 1, p.9-17, 2015. Avaialable: < http://dx.doi.org/10.5902/2316980X17061 > Acessed in: 10 dez. 2019.

GOMES, J.M.; PAIVA, H.P. Viveiros florestais (propagação sexuada). 3. Ed. Viçosa: UFV, 2012. 116 p.

LENHARD, N.R. et al. Crescimento de mudas de pau-ferro sob diferentes níveis de sombreamento. Pesquisa Agropecuária Tropical, Goiânia, v. 4, n. 2, p.178-186, 2013. Avaialable: http://www.scielo.br/pdf/pat/v43n2/v43n2a12 > Acessed in: 10 fev. 2019.

LISBOA, A.C. et al. Crescimento e qualidade de mudas de Handroanthus heptaphyllus em substrato com esterco bovino. Pesquisa Florestal Brasileira, Colombo, v. 38, p.1-6, 2018. Avaialable: <doi: 10.4336/2018.pfb.e201701485> Acessed in: 10 dez. 2019.

LORENZI, H. Árvores brasileiras: manual de identificação e cultivo de plantas arbóreas nativas do Brasil. v. 01. Nova Odessa, SP: Instituto Plantarum de Estudos da Flora Ltda. 2008. 384p.

NERY, F.C. et al. Desenvolvimento de mudas de guanandi (Calophyllum brasiliensis Cambess.) sob diferentes condições de sombreamento. Revista Brasileira de Biociências, Porto Alegre, v. 14, n. 3, p.187-192, 2016. Avaialable: < http://www.ufrgs.br/seerbio/ojs/index.php/rbb/article/view/3656/1333 > Acessed in: 20 dez. 2019.

OLIVEIRA, L.C.; HOPKINS, M. Parkia in Flora do Brasil 2020 em construção. Jardim Botânico do Rio de Janeiro. 2018. Avaialable: <http://reflora.jbrj.gov.br/reflora/floradobrasil/FB23108 11 Jun. 2018>. Acessed in: 25 jun. 2018.

PADILHA, M.S. et al. Crescimento de mudas de canafístula com o uso de adubação biológica e bioestimulante em diferentes substratos. Enciclopédia Biosfera, Goiânia, v. 15, n. 27, p.25-27, 2018. Avaialable: < DOI: 10.18677/EnciBio_2018A32 > Acessed in: 25 jun. 2019.

PINTO, J.R.S. et al. Crescimento e índices fisiológicos de Tabebuia aurea, sob sombreamento no semiárido. Floresta, Curitiba, v. 46, n. 4, p.465-472, 2016. Avaialable: < http://dx.doi.org/10.5380/rf.v46i4.42665 > Acessed in: 25 out. 2019.

REIS, S.M. et al. Influência do sombreamento no desenvolvimento inicial e eficiência no uso de nutrientes de Dilodendron bipinnatum Radkl (Sapindaceae). Scientiae Forestalis, São Paulo, v. 43, n. 107, p.581-590, 2015. Avaialable: < https://www.ipef.br/publicacoes/scientia/nr107/cap09.pdf > Acessed in: 10 dez. 2019.

RESENDE, S.V. et al. Influência da luz e substrato na germinação e desenvolvimento inicial de duas espécies de Calliandra Benth. (Mimosoideae - Leguminosae) endêmicas da Chapada Diamantina, Bahia. Revista Árvore, Viçosa, v. 35, n. 1, p.107-117, 2011. Avaialable: <http://dx.doi.org/10.1590/S0100-67622011000100013> Acessed in: 15 dez. 2019.

ROSA, L.S. et al. Emergência, crescimento e padrão de qualidade de mudas de Schizolobium amazonicum Huber ex Ducke sob diferentes níveis de sombreamento e profundidades de semeadura. Revista Ciências Agrárias, Manaus, v. 1, n. 52, p.87-98, 2009. Avaialable: https://periodicos.ufra.edu.br/index.php/ajaes/article/view/126/21> Acessed in: 15 dez. 2019.

SANTOS, L.W.; COELHO, M.F.B.; AZEVEDO, R.A.B. Qualidade de mudas de pau ferro produzidas em diferentes substratos e condições de luz. Pesquisa Florestal Brasileira, Colombo, v. 33, n. 74, p.150-157, 2013. Avaialable: < https://doi.org/10.4336/2013.pfb.33.74.344 > Acessed in: 10 set. 2019.

SOUZA, M.C.M.R. et al. Tolerância à salinidade e qualidade de mudas de noni sob diferentes ambientes e matéria orgânica. Revista Brasileira de Agricultura Irrigada, Sobral, v. 11, n. 7, p.2052-2062, 2017. Avaialable: < https:// http://inovagri.org.br/revista/index.php/rbai/article/view/682/pdf_419> Acessed in: 10 set. 2019.

TAIZ, L. et al. Fisiologia e Desenvolvimento Vegetal. São Paulo: Artmed, 6 a Ed. 2017, 888p.

TRAZZI, P.A. et al. Estercos de origem animal em substratos para a produção de mudas florestais: atributos físicos e químicos. Scientiae Forestalis, São Paulo, v. 40, n. 96, p.455-462, 2012. Avaialable: < https://www.ipef.br/publicacoes/scientia/nr96/cap03.pdf > Acessed in: 10 dez. 2019.

VALADÃO, M.B.X. et al. Initial development and biomass partitioning of Physocalymma scaberrimum Pohl (Lythraceae) under different shading levels. Scientiae Forestalis, São Paulo, v. 42, n. 101, p.129-139, 2014. Avaialable: < doi: 10.4336/2018.pfb.e201701485> Acessed in: 20 jan. 2019. 
VIEIRA, C.R.; WEBER, O.L.S.; SCARAMUZZA, J.F. Resíduos orgânicos como substrato para produção de mudas de guanandi. Uniciências, Cuiabá, v. 18, n. 2, p.91-97, 2014. Avaialable: $<$ http://dx.doi.org/10.17921/1415-5141.2014v18n2p\%25p> Acessed in: 20 fev. 2019.

ZANATTA, T.P. et al. Análise do desenvolvimento inicial de mudas de Tabebuia impetiginosa submetidas a diferentes tipos de substratos. Revista do Instituto Florestal, São Paulo, v. 28, n. 2, p.103-109, 2016. Avaialable: < DOI:10.24278/2178-5031.201628202 > Acessed in: 10 dez. 2019. 